\title{
AN EVALUATION OF THE INFLUENCE OF PUPILS' EATING HABITS ON THEIR ACADEMIC PERFORMANCE IN THE CONTEMPORARY SCHOOL SYSTEM
}

\author{
Egede, Bernadette Amukahara Joy (PhD) \\ College of Education, Agbor, \\ Delta State, Nigeria. \\ bajegede@yahoo.mail.com
}

\begin{abstract}
The nexus between academic performance, nutrition and eating habit is globally recognized to the extent that it has inspired various strategies such as 'school feeding programmes' in many nations including Nigeria. This correlational study was aimed to evaluate the relationship between the eating habits of primary school pupils and their academic performance, using a survey design. Fifty pupils in two intact classes from two schools in rural areas, formed the sample. Data was collected using interviewer-questionnaire, coupled with naturalistic observation, for the eating habits and their results from the term's examination done within the same periodin the schools. The data was analyzed using SPSS - 23 to determine the correlation coefficients. The results suggest that there is strong relationship between pupils' eating habits, in terms of frequency of feeding, quality of feeding pattern, and quality of breakfast and their academic performance. In addition, the pupils perceived that eating light breakfast enhances their attention span to learn unlike, skipping of breakfast and eating heavy breakfast. The results of this study provide empirical evidence which can be used to encourage parents in rural areas to provide adequate nutrition for their wards/children to enhance their performance in school as recommended in this paper.
\end{abstract}

Keywords: Eating habits, Academic performance, Primary school, Pupils, nutrition. 


\section{Introduction}

In the past two decades, there has been a profound global attention on the nutrition of everyone in the world. The nations of the world, through the United Nations (UN) have made concerted efforts to achieve healthy nutrition for everyone including children, via a variety of interventions, strategies, plans, frameworks and goals. The second International Conference on Nutrition (ICN2) was organized by Food and Agriculture Organization (FAO), and World Health Organization (WHO) in 2014 to address major nutrition challenges in the world among others (FAO/WHO, 2015). The comprehensive implementation plan on Maternal, Infant and Young Child Nutrition (2012 - 2025) was launched to reduce childhood wasting, overweight and stunted growth in children (WHO, 2014). Furthermore, the UN decade of Action on Nutrition (2016 - 2025) was declared as a commitment by the United Nations Member States to undertake 10 years of sustained and coherent implementation of policies, programmes and increased investments to eliminate malnutrition in all its forms, everywhere, leaving no one behind (UN, 2016). This was aimed at accelerating the implementation of ICN2, achieve Global Nutrition and diet-related NCD targets by 2025 and realize the Sustainable Development Goals (SDGs) by 2030. The second goal of the laudable SDGs, zero hunger, implies reduction of malnutrition (UN, 2015). The nexus between nutrition, health and education is glaring in the SDGs $(2015$ - 2030), the Global Strategy for Women's Children's and Adolescent's Health (2016 - 2030) and the emerging FAO - School Food and Nutrition framework (FAO, 2019) which was aimed at harnessing the benefit of this connectedness. Achieving the Education For All (EFA), 2000 - 2015, was not easy in places where there were vulnerable children, poorly funded education system and poverty. "Only a third of the countries reached global education goals (UNESCO, 2015). Poverty, health, education and nutrition has been seen, (in the light of challenges encountered in previous interventions) to interact mutually. Hence FAO (2004) considered the incorporating of nutrition into development. "Nutritional status is internationally recognized as an indicator of national development" (FAO (2004). This synergy between education, nutrition and health has been exploited by nations to make policies on nutrition (in addition to education), and researchers to study the interactions between the variables.

Nigeria has operated the following policies and plans on nutrition.

- National policy on Food and Nutrition (2013).

- The national policy on Infant and Young Child Feeding (IYCF), 2010.

- National Strategic Plan of Action for Nutrition (2014 - 2019).

Recently, Nigeria operated the Home- Grown School Feeding Strategic Plan, 2016 - 2020; in 12 (out of 36) states and the Federal Capital Territory (FCT). The plan was aimed at reducing hunger and malnutrition among school children in the bid to achieve education for all goals (universal basic education) FGN (2004). In this plan, a free nutritionally balanced hot meal per day was provided for the pupils in public primary schools, in the selected schools in the six geopolitical regions of the country. This has attracted several studies (Taylor \& Ogbogu, 2016; Eigbobo\&Onyejaka, 2020; Ajani, 2009; Olumuyiwa et al, 2012; Oluwakemi, et al 2014; Banwat, et al, 2020; and Oladaya\& Tinubu, 2020). The results of the studies suggest that the school feeding enhanced school enrolment, school attendance, health and academic performance of the pupils amidst the challenges encountered in the implementation. Similar results were obtained from studies in other countries that have practiced home-grown school feeding (Maset \&Aulo, 2013, World Bank \& World Food Programme 2012; Rono, 2010). 
In other parts of the country, Nigeria, where school feeding is not practiced, studies have also shown that nutritional status and habits of learners, at both secondary and primary school levels, have influence on academic performance (Rotimi, 2012, Opoola et al, 2016, Alejandra, et al, 2016; Maliki, 2018; Naira Project, 2020, Omuemu et al 2020). It is therefore pertinent to describe empirically the influence of nutritional factors on the academic performance of children especially in this period of UN decade of Action on Nutrition. World records showed that the percentage of primary school children in the rural areas $(67.34 \%)$ is almost twice that in the urban areas (32.66\%) in Nigeria (World Bank Survey, 2018). This study is focused on this all-important issue of nutritional habits of primary school children in a rural setting. Specifically, this study is set to evaluate the influence of pupils' eating habits on their academic performance in this present school system. The contemporary school system requires the communities and parents to be empowered with such important knowledge of the influence of the eating habits of their children so that they can be supportive in the achievement of the global goals in education, nutrition and health discussed in this paper.

\section{Theoretical Background}

Eating habits of children: Eating habit describes the way and how people eat, the type of food they eat, with whom they eat, the ways they obtain, process and even discard their food. It is influenced by many factors such as individual differences, cultural, social, religious and economic background, including their environment and educational status. It is also often influenced by policies of nations such as the ones which promote exclusive breasting of babies.

Good eating habit helps in the intake of balanced diet which promotes good nutritional status of a child (Otuneye, et al., 2017). Some indicators of good eating habit for school children are as follows.

- Eating variety of vegetables daily

- Eating whole grains high in fiber, such as bread and cereals

- Eating variety of fruits

- Drinking fat-free milk or low fat-milk

- Eating variety of protein foods and oils (Ward, 2021)

This study focuses on the type of food the school children ate as they attend school and how their feeding is planned in a rural setting. The rural setting is characterized by higher percentage of parents who are of lower socio- economic status, hurrying out early in the morning for wage-earning jobs, skipping breakfast for family members, or eating heavy breakfast as they farm in distant places. Ward (2021) prescribed that pupils must take breakfast before coming to school even if on the run, in addition to eating at school. Agu (2018) listed common foods in Nigeria which are ideal for children's good eating habit on a daily basis. They are - cereals, milk, boiled egg, fruit/fruit juice, rice and beans with beef, stew, semolina (or any fufu) with vegetable soup, meat or chicken. Furthermore, IQ Platter (2021) specified some food items which should be in the lunch bag of the child on daily basis, in the Nigerian environment. They included, spaghetti, banana, chicken, noodles, boiled egg, peanut, butter, sandwich, rice and stew, beans and dodo (fried ripe plantain), with stew. These were adapted to categorize the quality of the eating habits of the school children used in this study. 


\section{Academic Performance}

Academic performance is simply a measure of a learner's achievement across various academic subjects. It determines a pupil's status in the class. It is evaluated in a number of ways especially through written or oral achievement tests. For this study, it is considered appropriate to focus on cognitive tests or examination the pupils have taken in their classes. Then, their marks or scores in the examinations are considered as measures of their academic performance (Adeyemo, 2011).

\section{Academic Performance, Intelligence and Nutrition}

Academic performance depends on many factors including mental ability or intelligence of the learner. Level of intelligence, which is measured in IQ (Intelligence Quotient) has been proved to be linked to brain development in early life. In the same vein, brain development is influenced by a child's nutrition and eating habit/feeding style. Hence there are concepts like "brain foods for kids" Krueger (2015). Seven of such brain foods for kids are eggs, yoghourt, greens, fish, nuts and seeds, oatmeal and apples and plums. In this study, the eating habit of the pupils will be categorized with respect to the ideas and standards discussed earlier (Ward, 2021, Agu 2018, IQ Platter 2021 and Krueger (2015), and its association with their academic performance will be evaluated.

\section{Research Questions/Hypothesis}

1. Is there any significant relationship between eating habit of pupils described in terms of (i) frequency of feeding (ii) quality of feeding pattern (iii) quality of breakfast and their academic performance?

2. What is their perception of the effect of their eating habit on their attention span during lessons at school?

Hypothesis: There is no significant relationship between the eating habit of pupils described in terms of (i) daily frequency of feeding; (ii) quality of daily feeding pattern and (iii) quality of breakfast and their academic performance.

\section{Methodology \\ Research Design}

This study is a descriptive survey since no variable was manipulated

Population and Sample: Primary Six Pupils in the rural areas of Ika South Local Government Area (LGA) of Delta State constitute the population of this study. Two intact classes of 50 pupils from two primary schools formed a judgment sample for this study. The sampling was based on the willingness of the schools and pupils to participate in the study. The sample size was informed by the financial constraint in this study, which was personally funded and on the rigor of the method of data collection which involved naturalistic observation and requiredresearch assistants for larger sample sizes. The schools are:

1. Obika Primary School, Agbor-Obi - 30 pupils

2. Baptist Mission Primary School, Alihamie - 20 pupils

These schools are in the rural part of the Local Government Area (Delta State -Wikipedia, 2021). The primary six level was used because pupils at that level should be able to recall foods eaten the previous day than the younger ones in a 24 - hour recall method used in this study. 


\section{Instrument for Data Collection}

The main instrument for data collection was the interviewer-administered questionnaire. The ten-item questionnaire is an adapted form of food records/frequency questionnaire, FFQ (Johnson, 2015) in which the respondents provide the information by themselves within 24hour recall limit. It has two parts, Section A which required the name of school and sex. Their names were not required so as to make them feel very free to respond honestly, but their serial numbers in the class were written at the back of the questionnaires, so as to identify and match their responses with their academic performance. The second part Section B has questions which requested for the frequency of feeding, breakfast-skipping, type of food, and amount of money brought to school for buying food. It also asked for their perception on the effect of their breakfast-feeding pattern on their attention span at school.

Validation of the Instrument: The questionnaire was first given to a parent and a teacher who are experienced in the concept of eating habit of primary school pupils, type of food they bring to school and the type of food parents prepare for their children in the environment of study. Their contributions helped in revising the items to include the usual types of food available in the locality and the variety of feeding patterns they observed. This enhanced the face validity of the questionnaire. Secondly, the coefficient of reliability, Cronbach's alpha of 0.83 is obtained from the responses of 28 pupils from primary six. This is judged high enough to be used for the study (Field, 2013).

\section{Data Collection}

Permission to participate in this study was obtained from the headmistresses of the schools. The pupils were briefed on the type of information required from them and given the freedom to participate or not. However, all the pupils in two intact classes used agreed to participate in the study. The questionnaires were personally administered to each of the pupils during their recess, with the help of a trained research assistant. Non-participant (naturalistic) observation method was used to confirm their responses such as the amount of money they brought to school, the food they brought and the snacks/food they brought at school. Their end of term results was collected from the headmistress of the schools and the pupils were identified by number (and not names) to ensure anonymity and enhance their freedom to participate. In this way, all the questionnaires were duly completed and collected for analysis.

\section{Data Analysis}

Academic Performance: A measure of this variable was obtained from pupils scores in the subjects; English Language, Mathematics, Nigerian Language, Basic Science and Technology (BST), Religion and National Values (RNV), Cultural and Creative Arts(CCA), which they were taught during the term. A mean score from their scores in the six subjects was calculated for each pupil.

The scaling method employed in measuring dietary intake described by Johnson (2012) was adopted in this study instead of the clinical methods of Omiemu \& Ogboghodo (2020) which evaluated the calorific value of the foods to obtain dietary diversity scores. In this study weights are assigned to the responses of the pupils according to their conformity with the standards discussed earlier (Agu, 2018, IQ food platter, 2021, Ward, 2021). For each subvariable, feeding frequency, quality of daily feeding pattern and quality of breakfast, a composite score is obtained as follows for each pupil. 


\section{Feeding Frequency}

(i) Taking Breakfast before coming to school -1 (ii) Eating food at school-1 (iii) Eating food at home after school - 1 (iv) Eating additional snack/fruits/juice etc at school - 1

Maximum composite score -4

\section{Quality of daily feeding pattern}

(i) Egg/fish/beef/chicken - 1; (ii) variety of fruits (banana, orange, mango, etc)/fruit juice etc - 1; (iii) variety of vegetables/soup/salad etc - 1; (iv) variety of preparation of beans/rice/yam/plantain/fufu/noodles with stew - 1; Tea \& Bread/butter/cornflakes/cereals in pap/yoghourt/nuts, etc -1 (vi) money brought for feeding at school ( $\$ 50$ and above) -1 .

Maximum composite score -6

\section{Quality of breakfast (if it is not skipped)}

(i) Egg (variety of ways) - 1 (ii) Fruits/Nuts/Vegetables - 1; (iii) Cakes/bean cakes/delicacies, e.g.moi-moi, (or beans pudding),corn-pudding, etc - 1; (iv) cereals in pap, e.g. custard, oat, corn, etc, - 1(v) Tea/milk/hot beverages - 1; (vi) Bread/sandwich/meat or fish pie/biscuits, etc -1 (vii) Heavy food - Rice /beans/fried plantain/potatoes/yam/etc - 1

* All items (i) - (vii) cannot be available in a meal, hence, maximum composite score is 5 . Where breakfast is skipped, the pupil scores 0 . These scores are subjected to normality tests and used to compute Pearson Product Moment Correlation coefficients so as to answer the research questions.

Perceptions of the pupils on the effect of their breakfast on their attention span during lessons: This was analyzed using frequencies, simple percentages and chi-square statistics.

\section{Results}

Hypothesis 1(i)

There is no significant relationship between pupil's frequency of feeding and their academic performance.

Table 1: Correlation between pupils' frequency of feeding and academic performance

\begin{tabular}{|c|c|c|c|}
\hline & & $\begin{array}{l}\text { Pupil's } \\
\text { frequency of } \\
\text { feeding (1) }\end{array}$ & $\begin{array}{l}\text { Pupil's } \\
\text { Academic } \\
\text { performance } \\
\text { (2) }\end{array}$ \\
\hline \multirow{3}{*}{$\begin{array}{l}\text { Pupils' frequency } \\
\text { feeding (1) }\end{array}$} & Pearson Correlation & 1 & $.452^{*}$ \\
\hline & Sig (2-tailed) & .000 & .000 \\
\hline & $\mathrm{N}$ & 50 & 50 \\
\hline \multirow{3}{*}{$\begin{array}{l}\text { Pupils' Academic } \\
\text { Performance (2) }\end{array}$} & Pearson Correlation & $.452^{\star}$ & 1 \\
\hline & Sig (2-tailed) & .000 & .000 \\
\hline & $\mathrm{N}$ & 50 & 50 \\
\hline
\end{tabular}

\section{* Significant at 0.05 level}

The normality tests were carried out using Shapiro-Wilk (probability $\mathrm{p}=0.08$ ) and Kolmogorov Smimov to establish normality. In addition, the Skewness and Kurtosis test indicates that the data for variables (1) and (2) in table 1 are normally distributed. 
Table 1 shows that there is significant positive relationship between pupils' frequency of feeding and their academic performance at 0.05 level of significance. This suggests that pupils' daily frequency of feeding was significantly related to their academic performance, $r$ $=.452, \mathrm{p}=.000$.

\section{Hypothesis 1(ii)}

There is no significant relationship between the quality of pupils' daily feeding pattern and their academic performance.

Table 2: Correlation between quality of pupils' daily feeding pattern and academic performance

\begin{tabular}{lllll}
\hline & & & $\begin{array}{l}\text { Quality of } \\
\text { daily feeding } \\
\text { pattern }\end{array}$ & $\begin{array}{l}\text { Academic } \\
\text { Performance }\end{array}$ \\
\hline 1 & Quality of daily feeding & Pearson Correlation & 1 & $.535^{*}$ \\
& pattern & Sig (2-tailed) & .000 & .000 \\
& & $\mathrm{~N}$ & 50 & 50 \\
2 & Academic Performance & Pearson Correlation & $.535^{*}$ & 1 \\
& & Sig (2-tailed) & .000 & .000 \\
& & $\mathrm{~N}$ & 50 & 50 \\
\hline
\end{tabular}

\section{* Significant at 0.05 level}

The skewness and Kurtosis test was used to establish that the data for variables (1) and (2) in table 2 above were normally distributed. The values of the ratio of the skewness and Kurtosis to their standard error values are respectively 1.45 and 1.08 which are less than the critical value of 1.96. The results in table 2 , showed that there is significant positive relationship between the quality of feeding pattern of pupils and their academic performance at 0.05 level of significance. The results suggest that the quality of feeding pattern of the pupils was significantly related to their academic performance.

\section{Hypothesis 1 (iii)}

There is no significant difference between the quality of breakfast taken by pupils and their academic performance.

Table 3: Correlation between quality of breakfast and academic performance

\begin{tabular}{lllll}
\hline & & & $\begin{array}{l}\text { Quality of } \\
\text { breakfast }\end{array}$ & $\begin{array}{l}\text { Academic } \\
\text { Performance }\end{array}$ \\
\hline 1 & Quality of breakfast & Pearson Correlation & 1 & $.337^{*}$ \\
& & Sig (2-tailed) & .011 & .011 \\
& $\mathrm{~N}$ & 50 & 50 \\
2 & \multirow{3}{*}{ Academic Performance } & Pearson Correlation & $.337^{*}$ & 1 \\
& & Sig (2-tailed) & .011 & .011 \\
& & $\mathrm{~N}$ & 50 & 50 \\
\hline
\end{tabular}

* Significant at 0.05 level 
The skewness and Kurtosis test showed that the ratio of their respective values to their standard error values are 1.07 for variable (2) and 1.21 for variable (1). Since these values are less than the critical values \pm 1.96 , normality of their distribution was assumed.

The results in table 3 showed a positive significant correlation between the quality of the breakfast and their academic performance at 0.05 level of significance. This suggests that the quality of the breakfast taken by pupils was significantly related to their academic performance.

The perception of the pupils on the effect of their breakfast on their attention span during lessons at school

Table 4: Frequency, percentage and Chi-square values $\left(\chi^{2}\right)$ for pupil's responses.

\begin{tabular}{llllllll}
\hline S/N & Item & $\begin{array}{l}\text { Freque } \\
\text { ncy } \\
\text { Yes }\end{array}$ & $\begin{array}{l}\text { Yes } \\
\text { ency }\end{array}$ & $\begin{array}{l}\text { Fo } \\
\text { Nrequ }\end{array}$ & No & $\begin{array}{c}\text { df } \\
\text { Chi- } \\
\text { square } \\
\chi^{2}\end{array}$ \\
\hline 1 & $\begin{array}{l}\text { Eating light breakfast makes me } \\
\text { concentrate to learn at school }\end{array}$ & 35 & 70 & 15 & 30 & 1 & $16.6^{*}$ \\
2 & $\begin{array}{l}\text { Eating heavy breakfast makes me } \\
\text { concentrate to learn at school }\end{array}$ & 15 & 30 & 35 & 70 & 1 & $16.0^{*}$ \\
3 & $\begin{array}{l}\text { Not eating breakfast makes me } \\
\text { concentrate to learn at school }\end{array}$ & 7 & 14 & 43 & 86 & 1 & $53.6^{*}$ \\
\hline
\end{tabular}

$\mathrm{N}=50 * \chi^{2}$ is significant, $\chi_{\mathrm{c}}{ }^{2}=3.84$ at 0.05 level, $\mathrm{df}=1$

Table 4 showed that significant number of pupils perceived that eating heavy breakfast (such as fufu and soup, beans and stew, or menu with many items) does not make them concentrate to learn at school $\left(\chi^{2}=16.0\right.$; df $\left.=1\right)$. It affects their attention span adversely. Similar perception is held by them for the skipping of breakfast before coming to school $\left(\chi^{2}=53.6\right.$; $\mathrm{df}=1$ ). Significant number of the pupils held the perception that eating light breakfast (bread and tea, bean-cake (akara) and pap, or menu small quantities of food items,) makes them concentrate to learn at school $\left(\chi^{2}=16.0, \mathrm{df}=1\right)$. The results suggest that generally, pupils perceived that eating heavy breakfast and skipping breakfast have adverse effect on their learning capacity, while eating light breakfast boosts their concentration to learn. These are borne out of their experiences, as required from them.

\section{Discussion of results}

Eating habit and academic performance: The results from this study suggested that the higher the frequency of feeding, the quality of feeding pattern and quality of breakfast, the higher the pupils' academic performance. In other words, the higher the pupils' frequency of daily feeding, quality of feeding pattern and quality of breakfast, the higher their academic performance. The results obtained in this study portray the reality of the situation observed. During the study, it was observed that the pupils who brought their food or bought food from the school food vendor were agile, lively and happy, eating their food and poised ready for their next lessons. On the contrary, those who didn't bring food or buy small snack expressed uneasy posture and moody look. The results corroborate those of numerous studies carried out in many countries using various research methods and designs, for various levels of young learners. Opoola et al. (2016) found that children who were well-fed and wellnourished tend to do better academically than those who were not. They used a survey design 
in which the body anthropometrics of primary 3 to 6 school children in Zaria, Nigeria, were measured. Rotimi (2012) found that secondary school students who had access to required balanced diet performed better than those who did not have. This study which was done in Ondo State, using survey design also showed that nourished students performed better academically than mal-nourished ones. Using clinical survey method, Omuemu et al. (2020) found that primary school children who skipped breakfast had higher proportion of low academic performance compared with those who did not. They concluded that breakfast skipping and low dietary diversity were significantly associated with poor academic performance of the study population drawn from an urban city in Southern Nigeria. In an inperson survey, Malki (2018) in California, U.S.A, found that students that were consuming two meals a day, breakfast and lunch, have grade-point average that is 139 points lower than those who had more meals per day. This highlights the significant relationship between frequency of feeding and academic performance as found in this study. The results of this study corroborate all the results obtained from studies on the effect of the school feeding programme (in Nigeria and in other countries) on academic performance of learners. The school feeding programme which enhances dietary nutrition in child was shown to enhance both enrolment and performance of pupils in schools (Taylor \& Ogbogu, 2016; Eigbobo \& Onyejaka, 2020; Ajani, 2009; Olumuyiwa, et al (2012); Oluwakemi, et al (2014); Oladayo Tinubu, 2020). Similar results in UK (McGregor, 2004); Egypt (Ibrahim, 2004); Malaysia, (Khor, 2004); Peru (Cueto, 2004) and Kenya (Bwibo, 2004) underscore the relationship between eating habit and academic performance as a universal phenomenon.

\section{Quality of feeding pattern and academic performance}

That the quality of feeding pattern is positively related to pupils' academic performance places a huge responsibility on all stakeholders who cater for children's nutrition especially the parents. To corroborate this point, studies have shown that the mother's level of education has inverse relationship with stunting in children (USAID, 2018). The latest statistics in Nigeria shows that $65 \%$ of the illiterate women reside in the rural areas (Statista, 2021). In addition, $43 \%$ of stunted children in the age range $0-5$ years live in the rural areas, (USAID, 2018) and some of them reach the school level of primary six used in this study. Furthermore, Nigeria is one of the poorest countries of the world with many malnourished children, having overtaken India as the poverty capital of the world (QuartzAfrica, 2018). Hence this result indicates the need to create a community awareness and education in the rural areas so as to achieve the global goals on nutrition and education discussed earlier.

\section{Quality of Breakfast and Pupils' Perceptions.}

It is a common experience for the agrarian residents in rural communities to eat heavy breakfast before going to their farms. At times the school children are compelled to eat similar foods, sharing it with family members before going to school. The result of this study corroborates those of many studies such as Cherry (2020) that eating breakfast is significantly related to pupils' performance in school.

However, there is controversy in research about the effect of heavy and light breakfast on the attention span of children. Nutrition experts suggest breakfasts should be lighter (300 - 400 calories) than lunch and dinner (500 - 700 calories). Experience has shown that some persons, including children experience sleepiness with heavy breakfast, which experts confirm to be possible when a person takes heavy meal rich in both protein and carbohydrates (Weather, 2020). This may be the reason the pupils in this study opined that light breakfast 
makes them concentrate more to learn. Their perception that skipping breakfast does not help them concentrate to learn is a reality proven by research. Although, it was not the focus of this study, the pupils' responses showed that some of them skipped breakfast, but it was not surveyed as a single variable. The pupils rightly perceive that skipping breakfast is not helpful for their learning.Parents in the rural settings should be educated to provide their children and wards with quality breakfast before they leave for school daily.

\section{Recommendations}

The results of this study suggest that although the meals eaten by the residents of rural communities may not be very nourishing, pupils who have better eating habits perform better academically. Hence the following recommendations are made.

1. Parents in rural communities should be systematically educated through the Parents' Teachers' Associations (PTA) of schools, on the importance of providing good nutrition for the academic achievement of their wards and children.

2. There is need to provide parents in rural communities, suggested meal plans for their children according to local available food products, by government through the ministries of education and agriculture and other allied bodies.

\section{Conclusion}

There are global goals to eradicate hunger, poverty and provide education for all for sustainable development in all nations, as discussed in the introduction part of this paper. This study surveyed the relationship between the eating habits of primary six pupils and their academic performance, in two rural schools. The results suggest that pupils whose eating habits are better performed better in school. The pupils also held a perception that eating light breakfast makes them concentrate to learn at school as against skipping or eating heavy breakfast. It is therefore concluded that optimal academic performance could be obtained by pupils in any rural community, if they are exposed to adequate eating habits, even with the locally available food items in their communities. 


\section{References}

Adeyemo, S. A. (2011). The Effect of teachers' perception and students' perception of physics class/learning environment and their academic achievement in senior secondary school physics. International Journal of Education, 2(1), 74-75.

Agu, Z. (2018). Nigerian Food time table for children. Retrieved from https://www.legit.ng/1163171-nigerian-food-time-table-children/html. on 24th April 2021

Ajani, O. I. Y. (2009). The Effect of School Feeding Programme On Primary

School Attendance in Rural Areas of Lagos State, Nigeria. African Journals

Online, Vol. 12, No. $1-2$.

Alejandra, N. M., Paula, C. M. \&Patricia, A. M. (2016). Study of Nutrition Habits in Primary School Students. Journal of Clinical Nutrition and Dietetics Vol. 2, No. 4:19.

Banwat, M., Fayenuwo, J. O., Pamtok, A. O. \& Okone, C. J. et al (2020). Comparing Dietary Practices and Nutritional Status of Children on School Feeding programme with others in Jos North Local Government Area, Plateau State. Retrieved from researchgate.net/publication/343343468 on 24/4/21.

Bwibo, N. (2004). Community-Based Efforts to provide food and its impact on school performance: The case of Makuemi District. Retrieved from www.international.ucla.edu/institute/article/8943 on 2/5/21

Cherry, K. (2020). An experiment on breakfast and school performance. Verywellmind.com. Retrieved on 2nd May 2021.

Cueto, S (2004). Height and Weight as predictors of Achievement, Grade repetition and drop-out in Rural Peru. Retrieved from www.international.ucla.edu/institute/article/8943 on 2/5/21.

Delta-Wikipedia (2021). List of Villages in Delta State by Wardshttps://en.m.wikipedia.org. Retrieved on 10/5/21.

Eigbobo, J.O., \&Onyejaka, N.K. (2020). Descriptive Study of School Feeding Practices in Nigerian Children and the Risk of Dental Caries. Journal of Advances in Medicine and Medical Research, Vol. 32, Issue 3. Pp $58-68$.

FAO (2004). Incorporating Nutrition considerations into Development Policies and programmes. Retrieved from www.fao.org/3/y5343e/y5343e00.htm//content on $24 / 4 / 21$.

FAO (2019). School Food and Nutrition Framework. Retrieved from www.fao/publication/card/en/c/CA4091EN/ on 24/4/21.

FAO/WHO (2015). Second International Conference on Nutrition (ICN2), Report of the Joint FAO/WHO Secretariat on the conference. Retrieved from https://www.fao.org/3/i4436e/i4436e/pdf on 24/4/21. 
Field, A. (2013). Discovering Statistics Using SPSS Statistics. London. Sage Publications Inc.

Ibrahim, S. (2004). Awareness of Teachers of the Influence between students' performance and Nutrition Status: Egypt Experience. Retrieved from www.international.ucla.edu/institute/article/8943 on 2/5/21

IQfood Platter (2021). Meal Plan for Nigerian School Lunch box ideas. Retrieved from https://iqfoodplatter.com/14-nigerina-school-lunch-box-ideas/ on 24/4/21.

Johnson, R.K (2012). Dietary Intake-How do we measure what people are really eating? Obesity Research, Vol 10; Issue 511 p. 635 - 685.

Khor, H. G. (2004). Nutritional Status and Academic performance among children in primary schools in Kuala Lumpur, Malaysia.Retrieved from www.international.ucla.edu/institute/article/8943 on 2/5/21

Krueger, A (2015). 7 Brain Foods for Kids. Retrieved from www.webmd.com.

MaGregor, S. (2004). Can the provision of food help children's school performance? Retrieved from www.international.ucla.edu/institute/article/8943 on 2/5/21

Malki, A. (2018). The Effect of Students' nutrition on Academic Performance. Retrieved from www.scholarworks.calstate.edu on 30/3/21

Maset, E. \&Aulo, G. (2013). Improving Community Development by linking agriculture, nutrition and education: design of a randomized trial of home- grown school feeding in Mali. Retrieved from www.trialsjournal.biomedcentral.com/articles on March, 2021.

Nairaproject (2020). Eating habit as a determinant of academic performance among secondary school students in Ikene Local Government Area. Retrieved from https://www.nairaproject.com on 24/4/21.

Oladayo, A. \& Tinubu, R. A. (2020). Impact Evaluation of National Home-Grown School Feeding Programme in Nigeria: Preliminary Findings from a Mixed-method Aproach. Retrieved from https://www.researchgate.net/publication/342881116 on 24/4/21.

Olumuyiwa, S. F., Olusegun, O., Oluwemimo, O, \& Wale, O. (2012). School Feeding Programme in Nigeria. The Nutritional Status of Pupils in a Public Primary School in Ile-Ife, Osun State, Nigeria Food and Nutrition Sciences, 03/05).

Oluwakemi, M. A., Kayode, O. O. \& Taiwo, O. (2014). A Qualitative Study on Status of Implementation of School Health Programme in South West Nigeria: Implications for Healthy Living of School Age Children in Developing Countries. American Journal of Education Research, 2 (11). P 1076 - 1087.

Omuemu, V. C. \&Ogboghodo, E.O. (2020). Nutritional factors and academic performance of primary school children in Urban City in Southern Nigeria. Retrieved from www.asianinstituteofresearch.org. on 24/4/21. 
Opoola, F., Adebisi, S., Ibegbu, A. O. (2016). The study of Nutritional Status and Academic Performance of primary school children in Kaduna State, Nigeria. Anals of Bioanathropology, 4(2), 96.

Otuneye, A. T., Amed, P.A., Abdulkarim, A. A., Aluko, O.O. \& Shatima, D. R. (2017). Relationship between dietary habits and nutritional status among adolescents in Abuja municipal area council of Nigeria. Niger J. paediatr., 44(3) p128-135.

QuartzAfrica (2018). Nigeria has become the poverty capital of the World. https://qz.com. Retrieved on 20/4/21.

Rono, R. (2010). Factors affecting pupils' performance in public primary schools at Kenya certificate of Primary Education Examination (KCPE) in Emawen Division, Nandi District Kenya. Retrieved from http://repository.uonbi.ac.ke/bitstream/handle/11295/52949/ABSTRACT.pdf? On $24 / 4 / 21$.

Rotimi, O. (2012). The Effects of Nutrition on Students' Academic Performance among secondary school students in Ondo State. Retrieved from https://www.grin.com on $30 / 3 / 21$.

Statista, (2021). Nigeria: Literacy rate. Retrieved from statista.com on 2/5/21.

Taylor, A. D. \& Ogbogu, C. O. (2016). The Effects of School feeding on Enrolment and Performance. World Journal of Education; Vol. 6, No. 3, p 40-47.

UN (2015). Take action for the SDGs. Retrieved from https://www.un.org/substainabledevelopment/sustainable-development- goals/ on $24 / 4 / 21$.

UN (2016). UN decade of Action on Nutrition. Retrieved from https://www.un.org>nutrition on $24 / 4 / 21$.

UNESCO (2015). Education For All 2000 - 2015. Achievements and Challenges. Retrieved from en.unesco.org. on 26/4/21.

Ward, E.M. (2021). Good Eats for School-age kids. Retrieved from https://wwwwebmd.com/parenting/features/good-eats-school-age-kids on 25/4/21.

Weather, D. (2020). Why do people feel tired after eating? Medicalnewstoday.com. Retrieved on $2 / 5 / 21$.

WHO (2014). Comprehensive Implementation Plan on maternal, Infant and Young Child Nutrition. Retrieved from www.who.int/nutrition/publication.CIP document/en/ on $24 / 4 / 21$

World Bank \& World Bank Programme (2012). Scaling up school feeding: Keeping children in school while improving their learning and health. Retrieved from https://www.worldbank.org/en/news/feature/2012/04/25. on 30/3/21. 
International Journal of Research in Education and Sustainable Development | ISSN: 2782-7666

Journal DOI: www.doi.org/10.46654/IJRESD

Vol. 1, Issue 5 (May, 2021) | www.ijaar.org

Article DOI: www.doi.org/10.46654/IJRESD.1560

World Bank Survey (2018). Society, Education, \& Science. Retrieved from www.statistica.com/topics/6658/educaiton-in-nigeria/ on 5/4/21. 